\section{IJ§ER}

ISSN: 2149-5939
International Journal of Social Sciences and Education Research

Online, http://dergipark.gov.tr/ijsser

Volume: 3(2), 2017

\title{
Matematik eğitimi felsefesi üzerine bir literatür taraması ${ }^{1}$
}

\author{
A literature review on consumption philosophy of mathematics education
}

\author{
Mehmet Kasım Koyuncu²
}

\author{
Ahmet Şükrü Özdemir ${ }^{3}$
}

\section{$\ddot{O}_{z}$}

Received Date: 10 / 03 / 2017

Accepted Date: $10 / 06 / 2017$

\begin{abstract}
Bu çalışmanın amacı, matematik eğitimi felsefesi üzerine kapsamlı bir literatür taraması yapmaktır. Bu doğrultuda "matematik eğitimi felsefesi" ne iliş̧kin ulusal ve uluslararası çalışmalar karşılaştırmalı okumaya tabi tutulmuştur. Elde edilen bilgiler, sanayi odakl eğitimciler, teknoloji odakl eğitimciler, eski hümanistler, ilerlemeci eğitimciler ve halkçı eğitimciler olmak üzere beş alt başlıkta toplanmıştır. Bu başlıklar altında toplanan bilgiler, açıklayıcı bir biçimde aktarılmaya çalışılmıştır. Çalışmanın sonuçlarına göre matematik eğitimi felsefesinin, matematik felsefesi içinde değerlendirilmesi gerektiği söylenebilir. Çünkü matematik eğitimi felsefesinin merkezi konulardan biri, matematik felsefesi ve matematiksel uygulamaların arasında bağlantı kurmaktır. Herhangi bir alanın felsefesi, o alanın amaçları ve gerekçeleri olarak ele alınabilir. Matematik felsefelerindeki farklılık, matematik eğitimindeki farklılı̆̆ın bir sonucu değil, bir sebebidir. Bu nedenle matematik eğitimi felsefesinden söz edebilmek için öncelikle matematik felsefesinden bahsetmek gerekmektedir. Yapılan literatür taramasında ülkemizde ortä̈ğretim düzeyinde matematik felsefesi ile ilgili çok az çalı̧̧manın yapıldiğı görülmektedir. Ayrıca matematik felsefesi etkinlikleri ile uyumlu ögretimle ilgili bir bilimsel araştırmanın bulunmayışı, yine yapılan literatür taraması sonunda ortaya çıkmıştır.
\end{abstract}

Anahtar sözcükler: Matematik felsefesi, eğitim felsefesi, matematik ĕgitimi felsefesi.

\begin{abstract}
The purpose of this study is to conduct a comprehensive literature review on philosophy of mathematics education. In line with this purpose, papers about "The Philosophy of Mathematics Education" have been collated benefit from the national and international researches. Gathered literature is divided into five sub heading as industrial trainers, technological pragmatists, old humanist, progressive educators, public educators. This obtained information has been tried to be explained in a descriptive way. According to the results of the study, it can be said that the philosophy of mathematics education should be evaluated in the philosophy of mathematics. Because one of the central issues in the philosophy of mathematics education is to link between the philosophy of mathematics and mathematical applications. The philosophy of some field can be considered as its aims or reason. The difference in philosophy of mathematics is not the result, but the reason, of the difference in philosophy of mathematics education. Therefore, it is first necessary to talk about the philosophy of mathematics in order to talk about the philosophy of mathematics education. A review of the literature has indicated that there is a lack of studies about the philosophy of mathematics education (in grades 9,10,11 and 12). The other gap lies in the fact that there is no research in concern with the mathematical philosophy activities, as is displayed after reviewing the literature.

Keywords:Philosophy of mathematics, philosophy of education, philosophy of mathematics education.
\end{abstract}

\footnotetext{
${ }^{1}$ Bu çalışma, Marmara Üniversitesi, Eğitim Bilimleri Enstitüsü, OFMAE Bölümü Matematik Öğretmenliği Anabilim Dalı, doktora öğrencisi Mehmet Kasım Koyuncu'nun “Matematik Felsefesinin Matematik Eğitimine Entegrasyonunun Öğrenciler Üzerindeki Etkileri” " başlıklı doktora tezinin literatür taraması kısmının bir bölümünden oluşmaktadır. ${ }^{2}$ Doktora öğrencisi, Marmara Üniversitesi, Eğitim Bilimleri Enstitüsü, OFMAE Bölümü Matematik Öğretmenliği Anabilim Dalı, İstanbul/Türkiye, mehmetkasimkoyuncu@gmail.com

${ }^{3}$ Prof. Dr. Ahmet Şükrü Özdemir, Marmara Üniversitesi, OFMAE Bölümü Matematik Öğretmenliği Anabilim Dalı, ahmet.ozdemir@marmara.edu.tr
} 
Koyuncu, M.K., Özdemir, A.Ş. (2017). Matematik eğitimi felsefesi üzerine bir literatür taraması. International Journal of Social Sciences and Education Research. 3(3), 1033-1040.

\section{Giriş}

Matematiğin kendi varlığının yanı sıra, felsefi diyebileceğimiz düşünsel bir yanı da vardır(Crilly, 2011). Matematik sözcügünün kökeni ise Eski Yunan'da "matesis”, "ben bilirim” sözcügünden gelmektedir(Sertöz, 1998).

Matematiğin diğer bütün bilimlerin üzerinde ayrıcalıklı olmasının sebebi, önermelerinin mutlak bir biçimde kesin, yanlışlanamaz ve tartışılamaz olmasıyken, diğer bilimlerin matematikten farkı bir noktaya kadar tartışılabilir olmaları ve keşfedilen olgularla yıkılma tehlikesini daima taşımalarıdır(Einstein, 2013).

Dünya tarihinde Thales, Pisagor, Euclides, Pascal ve Newton önemli matematikçiler olarak gösterilmektedir(M.E.B., 2016). Bu matematikçilerin aynı zamanda birer filozof oldukları da bilinen bir gerçektir.

MÖ 427- MÖ 347 yılları arasında yaşamış olan Plato, hem kendinden sonra gelen bilim insanlarına ilham vermesi hem de fikirleriyle onları yönlendirmesi nedeniyle matematik tarihinde önemli bir yere sahiptir(C.Merzbach, Uta; Boyer, Carl B, 1991).

Bunun yanında Aristoteles mantık biliminin kurucusu olarak bilinir. Ondan önce Elea Okulu ve sofistler bu bilimin kurulması için çalışmışlardır. Tartışmalarının odak noktası mantıklı düşünme kavramı olmuştur. Fakat mantık ilk olarak Aristoteles tarafından kurulmuştur (Öner, 1986).

Modern felsefenin kurucusu olan Descartes, geometrik metotların, felsefi doktrinleri açıklamak ve demonstre etmek için uygulanabileceğini iddia ediyordu. Descartes bu düşünceler eşliğinde analitik geometriyi kurma başarısını göstermişti(McKeon, 1930).

Ayrıca sonsuz küçükler hesabını geliştiren Alman matematikçi ve filozof Gottfried Wilhelm Leibniz "Matematik olmadan felsefeye derinlemesine nüfuz edemeyiz. Felsefe olmadan da matematiğin derinliklerine nüfuz edemeyiz. Her ikisi olmaksızın herhangi bir şeye nüfuz edemeyiz" demiştir(Baki, 2014).

\section{Literatür}

Matematik eğitiminin amaçları oldukça tartışmalı bir alandır. Matematiğin doğasını ve amaçlarını farklı matematik felsefeleri ile ele alan beş farklı grup vardır. Bu gruplar ve amaçları şu şekildedir:

\subsection{Sanayi odaklı eğitimciler}

Sanayi odaklı eğitimciler için matematik eğitiminin amacı; bireyin matematiğe yatkın olması ve aynı zamanda bu yatkınlığın işlevsel olması gerekir. Öte yandan ikinci bir amaç ise itaattir.

Matematik gerçeklerden ve becerilerden oluşan açık bir bilgi birikimidir (Lawlor, 1988; akt. Ernest, 2004). 'Basit matematiğin anlaşılması' becerilere dahildir. $2+2=4$ eşitliği ise; matematiksel bir gerçektir (Letwin, 1988; akt. Ernest, 2004). Okul matematiği diğer bilgi alanlarından açık bir şekilde ayrılmıştır ve müfredat dışı bağlantılarla sosyal değerlerden uzak tutulmalıdır (Lawlor, 1988; akt. Ernest, 2004). Matematikte toplumsal nesnelerin yeri yoktur (Campaign for real education, 1987; akt. Ernest, 2004). Matematik tamamen tarafsızdır ve yalnızca sayı ve hesaplama gibi nesnel içeriklerle ilgilenir (Ernest, The Philosophy of Mathematics Education, 2004). 
Koyuncu, M.K., Özdemir, A.Ş. (2017). A literature review on consumption philosophy of mathematics education. International Journal of Social Sciences and Education Research. 1033-1040.

Sanayi odaklı eğitimciler için öğrenme; bireysel talep, özveri ve çabaya bağlıdır. Öğrenme 'sıkı işgücü' veya 'çalışma' benzetmeleri ile temsil edilir. Buna ek olarak öğrenme; izole ve bireyseldir (Ernest, The Philosophy of Mathematics Education, 2004).

Sanayi odaklı eğitimcilerin öğretim teorisi otoriterdir. Katı disiplin ve bilgi aktarımını içerir. Öğretim, bir miktar bilgi birikiminin karşı tarafa aktarılması anlamına gelir (Lawlor, 1988; akt. Ernest, 2004). Ahlaki değerlerin korunabilmesi için; sıkı çalışma, çaba ve öz disiplin şarttır. Öğretim; öğrenme, ezberleme, uygulama yapma şeklinde gerçekleşir. Öğretim süreci boyunca; etkinliklere, çeşitli materyallere, farklı düşünceleri araştırmaya gerek yoktur. Matematik 'eğlenmek' demek değildir (Prais, 1987; akt. Ernest, 2004).

\subsection{Teknoloji odaklı ĕgitimciler}

$\mathrm{Bu}$ grubun matematik öğretimine yönelik amaçları faydacıdır. Teknoloji odaklı eğitimcilere göre; yetişkin birer birey olduklarında istihdam edilebilmeleri için; öğrencilere uygun seviyede matematik öğretilmelidir. Bu amaç üç yan bileşen içermektedir:

1. Öğrencilere ihtiyaç duyacakları matematik bilgi ve becerileri kazandırmak,

2. Öğrencilerin istihdam edilmelerine yardım için; matematiksel kazanımlarını belgelemek,

3. Kapsamlı teknolojik eğitimle bilgisayar bilinci ve bilgi teknolojisi becerileri kazandirmak.

Teknoloji odaklı eğitimcilere göre okul matematiği iki kısımdan oluşmaktadır: Birinci kısım; saf matematiksel beceriler, usuller, gerçekler ve bilgiyi içerir. Bunlar konunun ana iskeletini oluştururlar. İkinci kısım; matematiğin kullanımı ve uygulamalarını içerir. $\mathrm{Bu}$, matematiğin hayati önem taşıyan ve çalışmaya motive eden kısmıdır. Okul matematiği dışa dönüktür. Öz değerler, üretkenlik ve model hiçe sayılamaz.

Bu eğitimcilerin öğrenmeye bakışı, sanayi odaklı eğitimcilerle benzerlik gösterir. Ciddi ve sıkı çalışmaya önem verirler. Ezberlemek, uygulama yapmak, problem çözmek beraberinde matematikte başarıyı getirir. (Ernest, The Philosophy of Mathematics Education, 2004)

Matematik öğretiminin odak noktası, matematik öğretme ve uygulama sanatıdır (Lighthill, 1973; akt. Ernest, 2004). Motivasyona önem verirler. Teknolojinin matematik öğretimini değiştirdiği inancını taşırlar. Bilgisayar destekli etkinliklerin eğitim programlarında yer alması bunun en büyük kanıtıdır(Ernest, The Philosophy of Mathematics Education, 2004).

\subsection{Eski hümanistler}

Bu topluluğun amacı; "matematik, matematik içindir" öğretisi doğrultusunda, matematiğin sadece kendisi için öğretilmesi ve saf matematiğin aktarılmasıdır.

Okul matematiği; öğrencilerde matematiksel düşünme becerisini, sanat ve estetik algısını geliştirmek için saf matematiksel bilgiyi içermelidir. Okul matematiği disiplinin kendisi gibi saf, hiyerarşik olarak yapılandırılmıştır. Hiyerarşide yukarıya çıkıldıkça, matematik giderek daha saf, titiz ve soyut hale gelir. Öğrenciler 'matematiksel kabiliyetlerine' göre bu hiyerarşiyi olabildiğince hızlı tırmanmaları için teşvik edilirler. Yükseldikçe, üniversite düzeyinde eğitim görmeye ve gerçek matematiğe daha da yaklaşırlar. 
Koyuncu, M.K., Özdemir, A.Ş. (2017). Matematik eğitimi felsefesi üzerine bir literatür taraması. International Journal of Social Sciences and Education Research. 3(3), 1033-1040.

$\mathrm{Bu}$ topluluğa göre; matematiksel zekâ ve matematik kabiliyeti bireye kalıtımla aktarılır. Öğrenme, saf matematik bilginin ve onunla ilişkili düşünce stillerinin anlaşılması ile alakalıdır.

Matematik; kültür, beşerî miras ve zihinsel başarının bir parçasıdır ve matematiksel bilgiden kasıt; bireye, değerlerin ve kültürün aktarılmasıdır. 'Saf matematik, saf düşünce kapasitesini geliştirir' tezini savunurlar. Saf matematiğin öğretilmesini bu yüzden istemektedirler. Öğretmen açıklayıcı rolündedir ve öğretim noktasında öğrencileri cesaretlendirmek ve güdülemek için görsel materyaller, modeller, kaynaklar kullanabilir. Gerçek matematik sadece başarı seviyesi yüksek öğrencilerle çalışılabilir. Uygulamalı matematik başarı seviyesi düşük öğrencilere yönelik olduğu için, öğrencilere bu kaynaklarla uygulama yapma şansı verilmez (Ernest, The Philosophy of Mathematics Education, 2004).

\section{4. İlerlemeci eğitimciler}

İlerlemeci eğitimcinin matematiksel amacı; genel eğitime katkıda bulunmaktır. Öğretim programlarının amacı; bireyin bireysel gelişimine katkı sağlamak olmalıdır (Ernest, The Philosophy of Mathematics Education, 2004).

Bu eğitimciler bilgi kuramı açısından hem deneyci hem de rasyonalisttirler. Marsh' a göre; bu ideolojinin odak noktası, deneyim ve çocuktur. Müfredat değil (Alexander, 1984; akt. Ernest, 2004). Matematik tüm çocukların gelişimi için bir araçtır. Matematik, tüm müfredatın yalnızca bir parçasıdır. Bu nedenle 'müfredat boyunca matematiğin' çocuklara yönelik uygulamaları okul matematiğinin bir parçası olarak değerlidir.

Bu topluluk öğrenciyi öğrenmenin merkezine koymakla birlikte; öğrenmenin araştırarak, keşfederek, problem çözerek, iş birliğine dayalı çalışarak gerçekleşeceğine inanmaktadır.

Okul matematiğinin merkezinde problem çözme olmalıdır. Öğretmen salt bilgi aktarımı yapmak yerine öğrenmeyi kolaylaştırmalıdır. Bunun için; öğrenme ortamlarının problem çözmeyi hedef alacak şekilde dizayn edilmesi gerekir (Ernest, The Philosophy of Mathematics Education, 2004).

\subsection{Halkçı ĕgitimciler}

Halkçı eğitimciler, yarı deneyselciliği ve sosyal yapılandırmacılığı benimsemişlerdir. Matematiğin icat olduğu görüşünü savunurlar. Onlara göre matematik insan zihninin bir ürünüdür ve dolayısıyla yanlışlanabilirdir. Halkçı eğitimciler matematiğin toplumun kültüründen bağımsız olmadığını düşünürler. Bu da bizi 'ethnomatematik' tanımına götürür. Ethnomatematik dediğimizde akla ilk gelen matematiksel düşüncenin toplum kültüründeki ifade biçimidir (Ercan, 2005).

Matematik, temelde sayılar, geometrik şekiller ve önceden belirlenmiş aksiyomlara göre tespit edilmiş kurallara ve tekniklere indirgenebilir. Bu epistemolojik bir konumlanmadır. Epistemolojik bu bakış açısı bilginin kültürel kuruluşunu da kapsar (Kuryel, 2009).

Halk eğitimcisine göre; demokratik vatandaşlık bilincinin geliştirilmesi matematikteki eleştirel düşünme sayesinde gerçekleşir. Okul matematiği, öğrencilerin kendilerini yabancılaşmış hissettikleri ve kendilerine dışarıdan dayatılan bir bilgi olarak görülmemelidir. Bunun yerine; okul matematiği öğrenci kültürüne yerleşmelidir. 
Koyuncu, M.K., Özdemir, A.Ş. (2017). A literature review on consumption philosophy of mathematics education. International Journal of Social Sciences and Education Research. 1033-1040.

$\mathrm{Bu}$ görüşe göre öğrenmenin merkezinde öğrenci olmalıdır. Matematiğe aktif olarak katılma, problemi ortaya çıkararak probleme çözüm üretme, geniş toplumsal bağlamları tartışma, çevrelerinde ve hayatlarında gizlenmiş olan matematiği ortaya çıkarıp tartışma öğrenciyi öğrenmenin merkezi haline getirecektir.

Halkçı eğitimciler, ‘herkes için eğitim' prensibini benimsemişledir. Onlara göre öğretim demokratik ve açık olmalıdır. Öğretmenin tartışmalarda taraf tutmayan yol gösterici ya da şeytanın avukatı rolünü üstlenmesi şarttır. Halkçı eğitimcilerin öğretim teorileri birtakım bileşenlerden oluşmaktadır. Örneğin; öğrencilerde özgüven tesis edebilmek için, grup çalışması, proje çalışması ve problem çözme gibi etkinliklere yer verilmelidir. Bununla birlikte öğrencilerden ders içeriğini sorgulamaları ve eleştirel düşünebilme kabiliyetlerini geliştirmeleri beklenir (Ernest, The Philosophy of Mathematics Education, 2004).

\section{Sonuç}

Matematik dünyasına önemli katkıları bulunan ünlü matematikçilerin hayatlarını incelendiğimizde çalıştıkları alanların sadece matematikten ibaret olmadığını kolaylıkla görürüz. Bu matematikçilerin çoğu hem matematik hem de felsefe alanında yeni ufuklar açmışlardır.

Matematik felsefesinde mantıkçılık, platonculuk, sezgicilik ve biçimcilik ana başlıkları altında sıralayabileceğimiz matematik felsefeleri vardır. Bir kimsenin hangi matematik felsefesini benimsediği, onun hangi matematik eğitimi felsefesini kabul ettiğini belli eder (Latterell, 2013).

Matematik felsefesi üzerine yazılmış olan bir eseri incelediğimizde, Cantor'un sonsuzluk ile ilgili incelemelerinin küme teorisinde açığa çıkan problemlerin ardından, bu problemleri yok etmek üzere bir temel probleminin açığa çıktığı, 30-40 yıllık süren çalışmaların sonuçsuz kaldığını görürüz. Esasında matematik felsefesi tüm zamanlara vardı; fakat matematiği bir temele oturtmak üzere, matematik felsefesi ile aktif olarak ilgilenilmesi, bu dönemin (matematiği bir temele oturtma arayışı) ayırt edici özelliğidir (Hersh, 1997).

Tarihe damgasını vurmuş olan bu matematikçilerin çalışmalarına baktığımızda matematiği ve felsefeyi beraber ele aldıklarını görürüz. Daha doğrusu matematikçi olmalarının yanında aynı zamanda birer filozofturlar. Tersine, filozof olmalarının yanında aynı zamanda birer matematikçiydiler. Matematik dünyasının önde gelen isimlerinden Gottlob Frege, Bertrand Russell, Alfred North Whitehead, Ludwig Wittgenstein, Willard Van Orman Quine, David Hilbert, Kurt Gödel, Gottfried Wilhelm Leibniz ve Bernard Bolzano gibi matematikçiler de aynı zamanda önemli birer filozoftular.

Hatta, Jostein Gaarder Sofi'nin Dünyası adlı eserinde Descartes’ten,

"Descartes felsefi konularda "matematiksel yöntemi" kullanmak istiyordu. Felsefi doğruları matematiksel bir kesinlikle kanıtlamak istiyordu. Felsefi konularda da sayllarla uğraşırken başvurduğumuz alete, yani aklımıza başvurmak istiyordu. Çünkü kesin bilgiyi yalnızca aklımız bize verebilirdi. Duyulara güvenilemeyeceği ortadaydı. Bu konuda Descartes'ın, matematik ve sayısal ilişkilerin duyulardan daha kesin bir bilgi sağladığını düşünen Platon'la aynı kanıda olduğunu söylemistik (Gaarder, 1994).”

şeklinde bahsetmektedir.

Matematik ve felsefe arasında böylesine sıkı bir yakınlık olmasına karşı1ık, yapılan literatür taraması sonucunda konu ile alakalı araştırmaların çok az sayıda olduğu ortaya çıkmıştır. Tüm 
Koyuncu, M.K., Özdemir, A.Ş. (2017). Matematik eğitimi felsefesi üzerine bir literatür taraması. International Journal of Social Sciences and Education Research. 3(3), 1033-1040.

bunları göz önünde bulundurduğumuzda gerek ulusal gerek uluslararası platformlarda matematik felsefesi etkinlikleriyle yapılan öğretimin araştırılmaması bir eksiklik olarak görülmüştür.

Yapılan literatür taramasında ülkemizde ortaöğretim düzeyinde matematik felsefesi ile ilgili çok az çalışmanın yapıldığı görülmektedir. Ayrıca matematik felsefesi etkinlikleri ile uyumlu öğretimle ilgili bir bilimsel araştırmanın bulunmayışı, yine yapılan literatür taraması sonunda ortaya çıkmıştır. Bu açıdan matematik felsefesi etkinlikleri ile öğretimin inanç, tutum ve matematiksel düşünme değişkenleri üzerindeki etkililiğini araştırmak önem arz etmektedir.

Sonuçta, matematik felsefesindeki sorunlar iki ana başlık altında toplanabilir. Birincisi, matematiksel epistemoloji ve ontoloji içeren temel problemler. İkincisi, matematik ve insan etkileşimini ele alan sorunlar ki. Bunlar, sadece matematikle veya felsefeyle ilgili değil; sosyal bilimlerin diğer dallarını da ilgilendirir (Ernest, What Is The Philosophy Of Mathematics Education, 2004).

\section{Kaynakça}

Baki, A. (2014). Matematik Tarihi ve Felsefesi. Ankara: Pegem Akademi.

C.Merzbach, Uta; Boyer, Carl B. (1991). A History of Mathematics (3rd Ed.). Hoboken, New Jersey: John Wiley \& Sons.

Crilly, T. (2011). Matematik Kullanım Klavuzu. (E. K1lıç, Çev.) İstanbul: Aylak Kitap Yayınları. Einstein, A. (2013). Bilim ve Felsefe Yazlları. (N. Bozkurt, Çev.) Ankara: Sentez Yayıncılık.

Ercan, B. (2005). Etnomatematik. Matematik Dünyası, 106.

Ernest, P. (2004). The Philosophy of Mathematics Education. Taylor \& Francis.

Ernest, P. (2004). What Is The Philosophy Of Mathematics Education. Philosophy of Mathematics Education Journal, 1-16.

Gaarder, J. (1994). Sofi'nin Dünyası. (G. Kutal, Çev.) İstanbul: Pan Yayıncılık.

Hersh, R. (1997). What is mathematics, really? New York: Oxford University Press.

Kuryel, B. (2009). Bir kültür olarak matematik. Toplumsal Tarih, 34-41.

Latterell, C. M. (2013). Matematik Savaşları. (A. Kolancı, Çev.) İstanbul: Doruk Yayımcılık.

M.E.B. (2016). Ortaöğretim Hazırlık Sınıfı Matematik Dersi Öğretim Programı. Ankara: M.E.B Yayınevi.

McKeon, R. (1930). Causation and the Geometric Method in the Philosophy of Spinoza (I). The Philosophical Review, 178-189.

Öner, N. (1986). Klasik Mantık. Ankara: Ankara Üniversitesi Basımevi.

Sertöz, S. (1998). Matematiğin Aydınlık Dünyası. Ankara: TÜBİTAK Yayınları. 
Koyuncu, M.K., Özdemir, A.Ş. (2017). A literature review on consumption philosophy of mathematics education. International Journal of Social Sciences and Education Research. 1033-1040.

\section{Extended abstract in English}

The purpose of this study is to conduct a comprehensive literature review on philosophy of mathematics education. In line with this purpose, papers about "The Philosophy of Mathematics Education" have been collated benefit from the national and international researches. Gathered literature is divided into five sub heading as industrial trainers, technological pragmatists, old humanist, progressive educators, public educators. This obtained information has been tried to be explained in a descriptive way. According to the results of the study, it can be said that the philosophy of mathematics education should be evaluated in the philosophy of mathematics. Because one of the central issues in the philosophy of mathematics education is to link between the philosophy of mathematics and mathematical applications. The philosophy of some field can be considered as its aims or reason. The difference in philosophy of mathematics is not the result, but the reason, of the difference in philosophy of mathematics education. Therefore, it is first necessary to talk about the philosophy of mathematics in order to talk about the philosophy of mathematics education. A review of the literature has indicated that there is a lack of studies about the philosophy of mathematics education (in grades 9,10,11 and 12). The other gap lies in the fact that there is no research in concern with the mathematical philosophy activities, as is displayed after reviewing the literature.

The philosophy of some area or activity can be understood as its aims or rationale. Mathematics education understood in its simplest and most concrete sense concerns the activity or practice of teaching mathematics. So, the narrowest sense of 'philosophy of mathematics education' concerns the aims or rationale behind the practice of teaching mathematics (Ernest, 2004). Which philosophy of mathematics someone adopts will determine which philosophy of mathematics education it accepts (Latterell, 2013).

When we examine a work that was written on the philosophy of mathematics in set theory of investigation related to Cantor's infinity, then the exposed problems, these problems which releases a basic problem to disappear, we see that fruitless 30-40 year period of the study. In fact, philosophy of mathematics was all the time; But actively dealing with philosophy of mathematics to set a mathematical basis is the distinguishing feature of this period (the search for mathematical justification) (Hersh, 1997).

When we look at the work of those mathematicians who have made mark in history, we see that they deal with mathematics and philosophy together. More precisely, they are mathematicians as well as philosophers at the same time. Conversely, they were also mathematicians besides being philosophers. One of the leading figures in the mathematics world Gottlob Frege, Bertrand Russell, Alfred North Whitehead, Ludwig Wittgenstein, Willard Van Orman Quine, David Hilbert, Kurt Gödel, Gottfried Wilhelm Leibniz and Bernard Bolzano these mathematicians are also are important philosophers too.

Descartes, the founder of modern philosophy, claimed that geometric methods could be applied to explain and demonstrate philosophical doctrines. Descartes had shown success in setting up analytical geometry in the context of these considerations (McKeon, 1930).

"Descartes was a mathematician; he is considered the father of analytical geometry, and he made important contributions to the science of algebra. Descartes wanted to use the 'mathematical method' even for philosophizing. He set out to prove philosophical truths in the way one proves a mathematical theorem. In other words, he wanted to use exactly the same instrument 
that we use when we work with figures, namely, reason, since only reason can give us certainty. It is far from certain that we can rely on our senses. We have already noted Descartes's affinity with Plato, who also observed that mathematics and numerical ratio give us more certainty than the evidence of our senses (Gaarder, 1994)."

Aristotle is known as the founder of the science of logic. Before that Elea School and the sophists worked for the establishment of this science. The focus of discussions has been the notion of rational thinking. But the logic was first established by Aristotle (Öner, 1986).

Plato, who lived between $427 \mathrm{BC}-347 \mathrm{BC}$, has an important place in the history of mathematics, both because it inspires the subsequent scientists and because it directs them with their ideas (C.Merzbach, Uta; Boyer, Carl B, 1991).

In the history of the world, Thales, Pythagoras, Euclid, Pascal and Newton are shown as important mathematicians. (M.E.B., 2016). It is also a fact that these mathematicians are philosophers too.

There are philosophies of mathematics that we can list under the main headings of logicism, platonism, intuitionism and formalism. Which philosophy of mathematics someone adopts will determine which philosophy of mathematics education he accepts (Latterell, 2013).

As a result, the problems of philosophy of mathematics can be grouped under two main headings. First, basic problems involving mathematical epistemology and ontology. The second is deal with mathematics and human interaction. These are not only about mathematics or philosophy but also other branches of social sciences (Ernest, What Is The Philosophy Of Mathematics Education, 2004). 